\title{
Apexification or Regeneration ? Repair in Endodontics
}

\author{
Apeksifikasyon mu, Rejenerasyon mu? Endodontide Onarım
}

\author{
Nimet GENÇOĞLU' ${ }^{1}$, Alev Eda OKUTAN²®, Ali MENTEŞ ${ }^{3}$
}

\begin{abstract}
Regenerative endodontics is a new concept for the management of the permanent immature teeth with necrotic pulps. This procedure enables to replace damaged dentine and pulp-dentin complex within the root structure with healthy tissue. Firstly, elimination of clinical symptoms of the infection then, thickening of the canal walls and continuing root maturation and finally filled with the host's own vital tissue are the main goals of regenerative endodontics. However, apexification is another solution associated with traditional root canal treatment for the teeth with necrotic pulp and immature root development. It involves removal of necrotic and infected tissue from the wide and funnel shape of root canal in immature teeth. The purpose of this article is to review regenerative endodontics and apexification in conjunction within a case.
\end{abstract}

Keywords: regenerative endodontics, apexification, MTA, immature permanent teeth

\section{$\ddot{O} z$}

Rejeneratif endodonti, apeksi açık nekrotik pulpalı daimî azı dişlerde uygulanan yeni bir tedavi konseptidir. $\mathrm{Bu}$ işlem, kök yapısındaki hasarlı dentin ve pulpa-dentin kompleksinin sağlıklı doku ile değiştirilmesini sağlar. İlk olarak enfeksiyonun klinik semptomlarının ortadan kaldırılması, ardından kanal duvarlarında kalınlaşma sağlanarak kök olgunlaşmasının devam etmesi ve son olarak da hastanın kendi vital dokusu ile kökün doldurulması rejeneratif endodontinin ana hedefleridir. Olgunlaşmamış dişlerde geniş ve huni şeklindeki kök kanalından nekrotik ve enfekte dokunun çıkarılmasını içeren apeksifikasyon işlemi, geleneksel kanal tedavisi ile ilişkili bir başka bir çözümdür. Bu makalede, aynı hasta üzerinde rejeneratif endodonti ve apeksifikasyon işlemleri farklı dişlerde uygulanarak tedavi prosedürü ve sonuçları gözden geçirilmiştir.

Nimet Gençoğlu (凶)

Marmara University, Faculty of Dentistry, Department of Endodontics, Istanbul, Turkey.

e-mail:ngencoglu@marmara.edu.tr

Alev Eda Okutan

Biruni University, Faculty of Dentistry, Department of Pediatric Dentistry, Istanbul, Turkey.

Ali Menteş

Marmara University, Faculty of Dentistry, Department of Pediatric Dentistry, Istanbul, Turkey.

Submitted / Gönderilme: 24.12.2020

Accepted/Kabul: 27.10.2021
Anahtar Kelimeler: rejeneratif endodonti, apeksifikasyon, MTA, olgunlaşmamış daimî dişler

\section{INTRODUCTION}

Root canal treatment is a rational treatment choice in a necrotic tooth. However, it may result in tooth loss, due to high risk of fracture and short root in an immature tooth. So, when the apex is not completely formed, care should be taken to treat necrosis or irreversible pulpitis. Endodontic management of the permanent immature tooth continues to be a challenge for both clinicians and researchers recently. Regenerative endodontics is a new technique for the management of immature and infected root canals and quite popular which results apexo-genesis with apical closure if it is indicated properly.

Conventional root canal treatment is carried out in mature teeth with completely closed apex. But in case of open apex, which residual progenitor pulp cells are not found in necrotic immature teeth, to complete root closure apexification, producing apical plug or regeneration procedure should be performed. Since the dentinal walls are quite thin in these teeth, clinical concerns are related to achieving disinfection as 'aggressive' instrumentation is contraindicated. So, clinician must rely on endodontic irrigants and medicaments mostly. Obturation is quite hard in open apex cases, because of difficulties in controlling the working length. Roots become weaker and fracture or tooth loss is unavoidable in long term due to mechanical instrumentation (Harlamb, 2016).

Apexification is one of the solution conjuncts with conventional root canal therapy in immature necrotic cases. It involves removal of necrotic and infected tissue from the wide and funnel shape of root canal in immature teeth. $\mathrm{Ca}(\mathrm{OH})_{2}$ is the most commonly used materials in treatment of immature teeth due to its high $\mathrm{pH}$ and strong antibacterial effect. Also, it's used for induction of an apical barrier. High accomplished 
results have been reported in clinical and experimental studies related to $\mathrm{Ca}(\mathrm{OH})_{2}$ applications (Andreasen and Andreasen, 1994). However, although apexification procedure with calcium hydroxide induces apex to close, it does not stimulate the thickness of the entire root dentin. So thin root dentin and large canal are prone to cervical fracture or insufficient root length leading to mobility and subsequent tooth loss in long term (Raldi et al., 2009).

MTA is widely used for apexification due to biocompability, ability to seal and its high $\mathrm{pH}$ as apical barrier. It produces an artificial barrier against obturation material to avoid overfilling and condensation forces. Although $\mathrm{Ca}(\mathrm{OH})_{2}$ produces biological barrier, it may weaken the dentin structure and must be replaced at monthly intervals (Yassen and Platt, 2013; Andreasen et al, 2002). However, MTA produces strong barrier and 24 hours after placement, root canal filling can be completed (Torabinejad and Walton, 2009).

Regenerative endodontics is one of the most stimulating improvements in dentistry. It uses the concept of tissue engineering (stem cells from an induced periapical bleeding and scaffold using blood clot, platelet rich plasma or platelet -rich fibrin) to restore the root canals to a healthy state, allowing for continued development of the root and surrounding tissue. The knowledge in the fields of pulp biology, dental trauma, and tissue engineering can be applied to deliver biologically based regenerative endodontic treatment of necrotic immature permanent teeth, resulting in continued root development, increased thickness in the dentinal walls and apical closure. These developments in the regeneration of a functional pulp-dentin complex have a promising impact on efforts to retain the natural dentition, the ultimate goal of endodontic treatment (AAE, 2018).

Nygaard-Ostby performed the first experimental study related to regenerative endodontics in 1961. He extracted an intact tooth and cut off apex; after replantation, he removed the pulp tissue through the crown of dog's teeth. Also, he ensured bleeding from humans' teeth after removal of necrotic pulp tissue, then obturated coronal part of teeth. A new vascular tissue was observed in unfilled apical portion of the experimental teeth (Ostby, 1961). In 1971, Nygaard-Ostby and Hjortdal demonstrated formation of fibrous connective tissue and accumulation of cellular cementum in the root canal after blood clot was created (Nygaard-Ostby and Hjortdal, 1971).

Later in 1978, Skoglund et al. detected occurrence of the revascularization in reimplanted and autotransplanted immature dog's teeth (Skoglund et al., 1978).
The width of the apical foramen is quite important in success of regeneration procedure. Kling et al. indicated that there is no revascularization of permanent teeth with less than $1 \mathrm{~mm}$ width of apical foremen which had been avulsed and reimplanted (Kling et al., 1986).

Regeneration procedure should be designed to replace damaged structures such as dentin, root structures and pulpdentin complex. Since biomechanical preparation cannot be done properly due to thin dentinal wall, irrigation is quite important for elimination infected tissue or debris. $1 \%$ $\mathrm{NaOCl}$ is optimum and higher percent of $\mathrm{NaOCl}$ might be irritant for vital tissue. Usage of EDTA is recommended for effect on PRP and viable cells (Iwaya et al., 2001). Also, triple antibiotic paste (ciprofloxacin, metronidazole and minocycline) is used for disinfection of the root canal. Hoshino et al. found that triple antibiotic paste (ciprofloxacin, metronidazole and minocycline, with and without the addition of rifampicin) effecting sufficiently on eradicating bacteria of the infected dentine in the root canal (Hoshino et al., 1996). Sato et al. found that triple antibiotic paste was effective on disinfection of infected canals (Sato et al., 1996). Allergic reactions or tooth discoloration was detected using of triple antibiotic medication. Kim et al. indicated that minocyclines discolored the coronal tooth structure (Kim et al., 2010). To avoid discoloration, cephalosporin or amocycilin are used instead of minocycline in triple antibiotic paste (Kim et al., 2010). Beside antibacterial effect of antibiotics, several other important effects are found on regeneration such as tetracycline enhances the growth of host cells on dentin via exposure of embedded collagen fibers or grow factors (Terranova et al., 1989). Beside antibiotics, $\mathrm{Ca}(\mathrm{OH})_{2}$ or $\mathrm{Ca}(\mathrm{OH})_{2}$ mixed with chlorhexidine was also used for this purpose. Chueh et al. also found that $\mathrm{Ca}(\mathrm{OH})_{2}$ was effective for elimination of bacteria in regeneration procedure (Chueh et al., 2008). However, usage of $\mathrm{Ca}(\mathrm{OH})_{2}$ was controversial due to its necrosis effect on vital tissue. Meantime, after blood clot was produced, MTA was used as an apical barrier in middle third of the canal in regeneration cases. Iwaya et al. recommended leaving the root canals free of medication for the vital pulp cells which had the potential to proliferate new pulp tissue (Iwayav et al., 2001). The first "revascularization protocol" was proposed by Banchs \& Trope as analogous to the regeneration guideline used today (Banchs and Trope, 2004). 


\section{Clinical Regenerative Endodontic Procedures}

The American Association of Endodontists suggests a
Clinical Considerations for a Regenerative Procedure for its members (Figure 1).

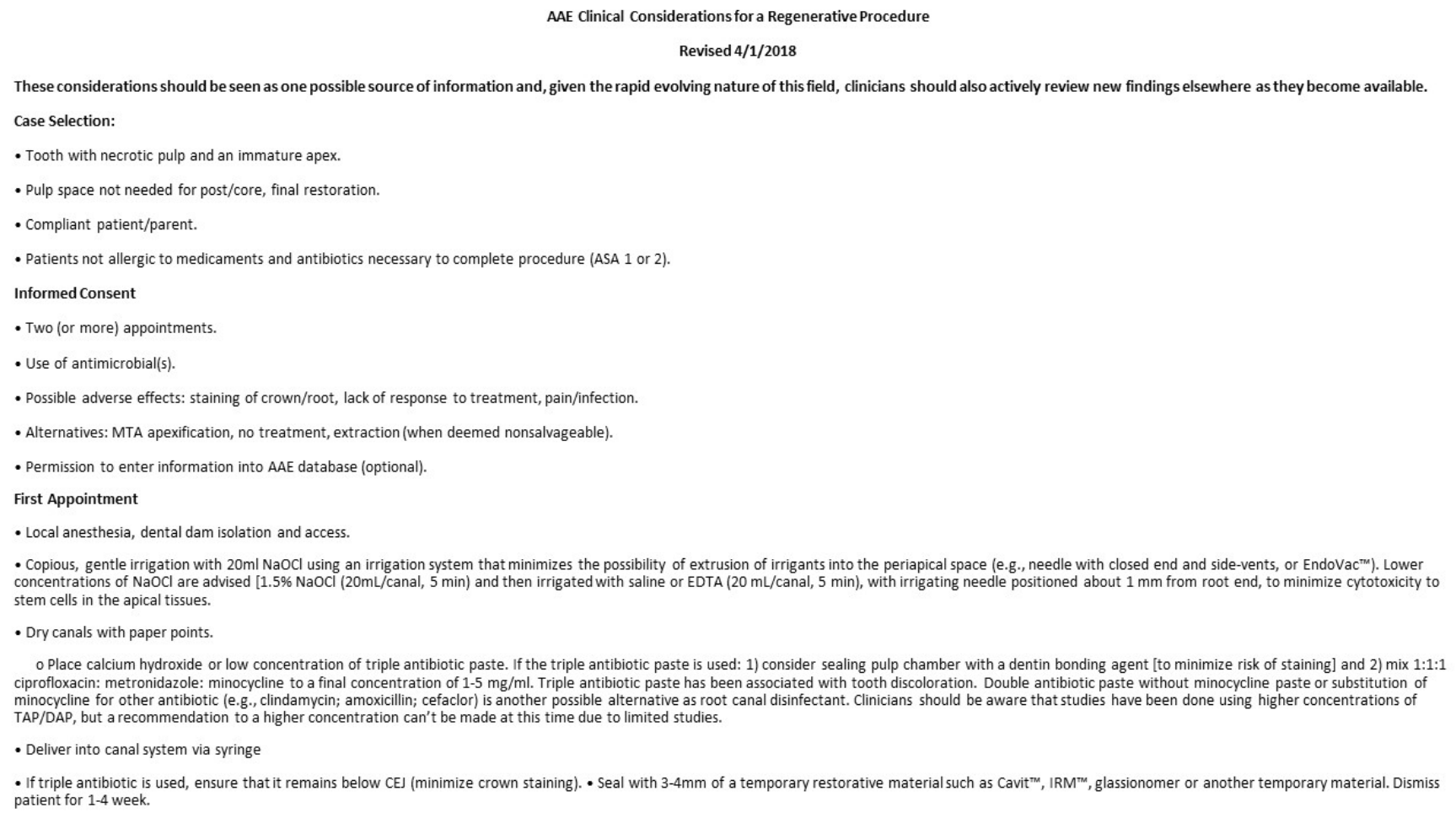

Fig 1. AAE Clinical Considerations for a Regenerative Endodontic Procedure

Basically, in the success of regenerative endodontic treatment, the clinician should firstly expect to eliminate the symptoms of the infection and heal the bone, then grow the root length and thickness, and finally receive a positive response to vitality test. 
In this article, comparative treatment options including regeneration and apexification procedure with open apices of the two maxillary central incisors with history of dental trauma was reported.

\section{Case Presentation}

A healthy 8-year-old girl with a history of trauma to her maxillary right and left central incisors was referred to dental clinic of Marmara University, Faculty of Dentistry Istanbul, Turkey. The patient had a history of bicycle injury 2 weeks ago and the crown fractures of \#11 and \#21 had been restored with composite restoration by a general dentist. The patient's main complaint was pain. Clinically pain was apparent on percussion. Radiographic examination showed no apical pathosis in immature root of the teeth. (Figure 2a) After signed informed consent was obtained from the patient's parent treatment of both teeth was initiated with a canal irrigation of $20 \mathrm{ml}$ of $5.25 \% \mathrm{NaOCl}$, without instrumentation and gently dried with paper points. Mixture of triple antibiotic paste was placed in both root canals.
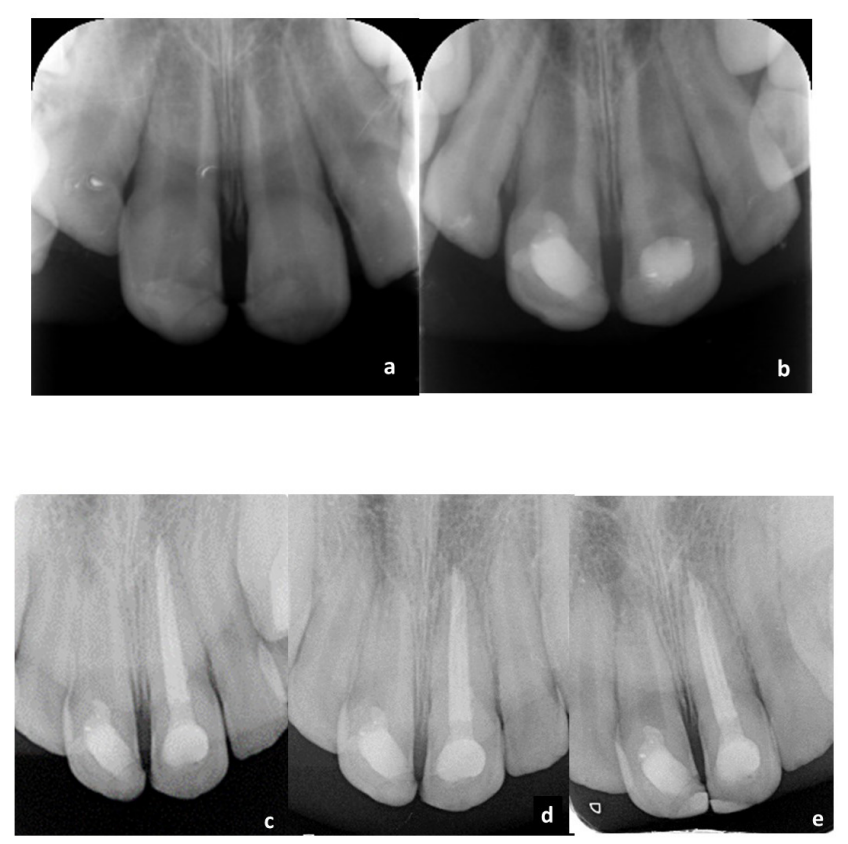

Fig 2. Regenerative and apexification treatment of the 2 central incisors.

a.Initial radiograph of the patient. b. Regenerative treatment of \#11 and apexification of \#21. c. Radiograph of one year after regenerative treatment on right maxillary incisor and apexification completed on left maxillary incisor. d. Two years follow up radiograph. e. Three years follow up radiograph.
2 weeks later, the treatment procedure was repeated due to respond to percussion test. Four weeks later, \#11 was asymptomatic no longer tender to percussion or palpation, so after irrigation a sterile \#20 K-file was used to induce bleeding within the root canal from the periapical tissues. MTA was placed and the tooth restored temporarily and one week later, permanent restoration was done with composite material. However, tooth \#21 was still tender to percussion and pain. Apexification procedure was decided to perform on tooth \#21 as an alternative approach. A creamy mixed of $\mathrm{CaOH}$ were replaced in several appointments for a year, after this period, the root length was increased, thickness of dentinal wall was observed and apical closure was evident on radiograph, so the root canal treatment was completed (Figure $2 \mathrm{~b}, \mathrm{c}$ ).

The case was followed up clinically and radiographically for three years. At follow-up examination of \#11 tooth was asymptomatic and functional, respond normal to cold and electrical pulp test but apical closure was not completed yet. Also, tooth \#21 was asymptomatic with no periapical pathosis in three years. (Figure $2 \mathrm{~d}, \mathrm{e}$ )

\section{DISCUSSION}

The success of regeneration treatment depends on three criteria: effective disinfection of the root canal, having more than $1 \mathrm{~mm}$ size of the apical foramen and the patient's age. Regards to these criteria, tooth \#11 was treated successfully.

Kahler et al. investigated 368 published clinical studies of treatment of immature teeth with pulp necrosis (Kahler et al., 2017). They found that $\mathrm{Ca}(\mathrm{OH})_{2}$ apexification treatment is standard endodontic procedure compared to obturating the root apices by MTA. The success rate was found $89.7 \%$ in conventional endodontic procedure, whereas $100 \%$ in obturated apices with MTA. However, Silujjai \& Linsuwanont found $80.77 \%$ success with apexification and $76.47 \%$ with regeneration cases (Silujjai and Linsuwanont, 2017). Authors considered success in Regenerative Endodontic Procedure (REP) by degree of apexogenesis including increased root length, increased root thickness and apical closure. They claimed that success rate can be affected due to clinical procedures such as operator skill, material selection and different protocols.

Nowadays regenerative endodontics is considered as the first treatment choice in open apices. However, if the clinical symptoms are not disappeared, apexification with $\mathrm{Ca}(\mathrm{OH})_{2}$ 
or closure of apex with MTA would be the treatment of choice.

In the present study, clinical symptoms such as swelling of the gingiva and pain in tooth \#21 could not be eliminated. So apexification with $\mathrm{Ca}(\mathrm{OH})_{2}$ treatment was preferred to REP. This case allowed us to compare both treatment options. As a result of the treatments, both teeth showed clinical success with increased root width and closed apices. Infection control is one of the success criteria in treatment of necrotic cases with open apices. It seems that race between new tissue and bacteria population in the pulp space result in healing. Almutairi et al. (2019) reviewed failed cases related to regenerative endodontics and found that $79 \%$ of these had persistent infections. In vivo studies showed that lack of periapical healing and thin root canal wall caused failure, most probably due to residual bacteria (Almutairi et al., 2019). Although antibiotics or $\mathrm{Ca}(\mathrm{OH})_{2}$ were used for intracanal medication, studies have indicated that most failed cases showed signs and symptoms of infection. When etiology of regenerative treatment cases was investigated, trauma found to be at the highest rate in failure (59\%). Dental trauma causes root resorption, and this may induce to damage dental papilla and Herwig epithelial root sheath which may cause the failure of regenerative endodontic treatment.

Controversial results were found related to one-visit REP (Shin et al., 2009). McCabe (2015) and Chaniotis (2016) found successful results with single visit, however failure cases were reported in one visit without use of intracanal medications.

American Association of Endodontics recommends lower concentration of irrigation solutions and medicaments for eliminating adverse effect of the chemical agents on radicular dentin or viable cells (AAE, 2018).

Alobaid et al. and Shimizu et al. reported crown fractures at the cervical level of immature tooth (Alobaid et al., 2014; Shimizu et al., 2013). Cvek indicated that immature teeth are susceptible to fracture specially in cervical third of the roots (Cvek, 1992). Yassen et al. reported that usage of $\mathrm{Ca}$ $(\mathrm{OH})_{2}$ or antibiotic-based medicament may decrease the fracture resistance of root (Yassen et al., 2013).

This study showed that regenerative treatment procedure can be considered as an alternative to apexification of tooth with immature apices when diagnosed properly. However, lately tissue engineering has been used to regenerate pulp tissue by applying stem cells, bioactive growth/ differentiation factors and biomimetric scaffold. Although so many experimental studies have been published until now, more studies are needed for the success of these types of cells in clinical cases.

\section{CONCLUSION}

REP for immature teeth versus $\mathrm{Ca}(\mathrm{OH})_{2}$ apexification/ MTA apical barrier procedures are quite popular and successful results were stated in literature. Potential of regenerative endodontics may benefit millions of patients each year. Although this high success rate of regenerative endodontics, much more effort should be given to reduce the high caries rate in our country and more importance to preventive dentistry in order to reduce early tooth loss. This report offers a good opportunity to compare two different treatment options on teeth with open apices and even though there was success in both treatments, regenerative treatment approach leads to the vitality of the pulp.

\section{ACKNOWLEDGEMENTS}

This study was supported by Marmara University Research Fund (Project No: 5595 cod: SAG-090.518.0240)

\section{REFERENCES}

1. Almutairi W, Yassen GH, Aminoshariae A, Williams KA, Mickel A. Regenerative Endodontics: A Systematic Analysis of the Failed Cases. J Endod. 2019 ;45(5):567-577.

2. Alobaid AS, Cortes LM, Lo J, Nguyen TT, Albert J, AbuMelha AS, Lin LM, Gibbs JL. Radiographic and Clinical Outcomes of the Treatment of Immature Permanent Teeth by Revascularization or Apexification: A Pilot Retrospective Cohort Study. J Endod. 2014; 40(8): 1063-1070.

3. AAE Clinical Considerations for a Regenerative Procedure. 2018.

4. Andreasen JO, Andreasen FM. Textbook and color atlas of traumatic injuries to the teeth. $3^{\text {rd }}$ ed. Munksgaard, 1994.

5. Andreasen JO, Farik B, Munksgaard EC. Long-term calcium hydroxide as a root canal dressing may increase risk of root fracture. Dental Traumatology, 18(3), 134-137.

6. Banchs F, Trope M. Revascularization of immature permanent teeth with apical periodontitis: new treatment protocol? J Endod. 2004;30(4):196-200.

7. Chaniotis A. The use of a single-step regenerative approach for the treatment of a replanted mandibular central incisor with severe resorption. Int Endod J. 2016;49(8):802-12.

8. Chueh LH, Ho YC, Kuo TC, Lai WH, Chen YH, Chiang CP. Regenerative endodontic treatment for necrotic immature permanent teeth. J Endod. 2009 Feb;35(2):160-4. 
9. Cvek M. Prognosis of luxated non-vital maxillary incisors treated with calcium hydroxide and filled with gutta-percha. A retrospective clinical study. Endod Dent Traumatol 1992; $8: 45-55$

10. Harlamb SC. Management of incompletely developed teeth requiring root canal treatment, Aust Dent J. 2016 ;61 Suppl 1:95-106.

11. Hoshino E, Kurihara-Ando N, Sato I, Uematsu H, Sato M, Kota K, Iwaku M. In-vitro antibacterial susceptibility of bacteria taken from infected root dentine to a mixture of ciprofloxacin, metronidazole and minocycline. Int Endod J. $1996 ; 29(2): 125-30$.

12. Iwaya SI, Ikawa M, Kubota M. Revascularization of an immature permanent tooth with apical periodontitis and sinus tract. Dent Traumatol. 2001 ;17(4):185-7.

13. Kahler B, Rossi-Fedele G, Chugal N, Lin LM. An Evidencebased Review of the Efficacy of Treatment Approaches for Immature Permanent Teeth with Pulp Necrosis. J Endod. 2017 Jul;43(7):1052-1057.

14. Kim JH, Kim Y, Shin SJ, Park JW, Jung IY. Tooth discoloration of immature permanent incisor associated with triple antibiotic therapy: a case report. J Endod. 2010 ;36(6):1086-91.

15. Kling M, Cvek M, Mejare I. Rate and predictability of pulp revascularization in therapeutically reimplanted permanent incisors. Endod Dent Traumatol. 1986 ;2(3):83-9.

16. McCabe P. Revascularization of an immature tooth with apical periodontitis using a single visit protocol: A case report. Int Endod J 2015;48(5):484-497.

17. Nygaard-Ostby B, Hjortdal O. Tissue formation in the root canal following pulp removal. Scand J Dent Res. 1971;79(5):333-49.

18. Ostby BN. The role of the blood clot in endodontic therapy. An experimental histologic study. Acta Odontol Scand. 1961;19:324-53.

19. Raldi DP, Mello I, Habitante SM, Lage-Marques JL, Coil J. Treatment options for teeth with open apices and apical periodontitis. J Can Dent Assoc. 2009 ;75(8):591-6.

20. Sato I, Ando-Kurihara N, Kota K, Iwaku M, Hoshino E. Sterilization of infected root-canal dentine by topical application of a mixture of ciprofloxacin, metronidazole and minocycline in situ. Int Endod J. 1996;29(2):118-24.

21. Shimizu E, Ricucci D, Albert J, Alobaid AS, Gibbs JL, Huang GT, Lin LM. Clinical, radiographic, and histological observation of a human immature permanent tooth with chronic apical abscess after revitalization treatment. J Endod. 2013 Aug;39(8):1078-83.

22. Shin SY, Albert JS, Mortman RE. One step pulp revascularization treatment of an immature permanent tooth with chronic apical abscess: a case report. Int Endod J. 2009 ;42(12):1118-26.

23. Silujjai J, Linsuwanont P. Treatment Outcomes of Apexification or Revascularization in Nonvital Immature Permanent Teeth: A Retrospective Study. J Endod. 2017 ;43(2):238-245.

24. Skoglund A, Tronstad L, Wallenius K. A microangiographic study of vascular changes in replanted and autotransplanted teeth of young dogs. Oral Surg Oral Med Oral Pathol. 1978 Jan;45(1):17-28.

25. Terranova VP, Odziemiec C, Tweden KS, Spadone DP. Repopulation of dentin surfaces by periodontal ligament cells and endothelial cells. Effect of basic fibroblast growth factor. J Periodontol. 1989; 60(6):293-301.

26. Torabinejad M, Walton RW. Endodontics Principles and Practice $4^{\text {th }}$ ed. Saunders\&Elsevier, 2009,p.33.

27. Yassen GH, Platt JA. The effect of nonsetting calcium hydroxide on root fracture and mechanical properties of radicular dentine: a systematic review. Int Endod J. 2013;46:112-118.

28. Yassen GH, Vail MM, Chu TG, Platt JA. The effect of medicaments used in endodontic regeneration on root fracture and microhardness of radicular dentine. Int Endod J. $2013 ; 46(7): 688-95$. 